https://doi.org/10.26593/sentris.v2i1.4613.105-120

\title{
Pendekatan Strategis dalam Persaingan: Interdependensi Finansial Amerika Serikat dan Tiongkok
}

\author{
Zulaekha Amalia \\ Fakultas Ilmu Sosial dan Ilmu Politik, Universitas Katolik Parahyangan, Indonesia, \\ zulaekhaamalia@gmail.com
}

\begin{abstract}
ABSTRAK
Tiongkok telah menjadi tantangan bagi kemajuan Amerika Serikat. Hal demikian didukung oleh fakta yang menunjukkan ketergantungan besar Amerika Serikat terhadap negara tersebut. Melalui kekuatan Tiongkok dari segi finansial dan ekonomi, Tiongkok mampu mengunci kekuatan Amerika Serikat di sistem internasional. Kondisi ini dapat menjadi ancaman berbahaya apabila kekuatan tersebut dijadikan instrumen ancaman negara. Maka, artikel ini bertujuan untuk menunjukkan bagaimana pengaruh finansial dan ekonomi Tiongkok dapat menjadi ancaman bagi Amerika Serikat dan dunia. Kemudian, artikel ini juga menyuguhkan interdependensi finansial yang ditinjau melalui utang besar Amerika Serikat terhadap Tiongkok dan kaitannya terhadap perdagangan Tiongkok serta analisis ancaman yang terjadi akibat kekuatan tersebut. Penulis menggunakan konsep Power dan Interdependence yang diuraikan oleh Robert O. Keohane dan Joseph S. Nye Jr. untuk menjadi kerangka berpikir analisis. Penelitian ini bersifat kualitatif yang berbasis studi kasus dengan perolehan data melalui kajian literatur dari sumber data terkait. Temuan dalam artikel ini menunjukkan bahwa Tiongkok memang memiliki pengaruh besar bagi keberlanjutan Amerika Serikat dan mau tidak mau kedua negara harus memiliki interdependensi yang kuat akibat ancaman yang dihadapi.
\end{abstract}

Kata Kunci: Tiongkok, Amerika Serikat, Finansial, Interdependensi

\section{ABSTRACT}

China has become a challenge to the advancement of the United States. This is supported by facts that show the great dependence of the United States. Through China's financial and economic power, China was able to lock in the power of the United States in the international system. This condition can be a dangerous threat if the power is used as state instrument. Therefore, this article will aim to show how China's financial and economic influence can pose a threat to the United States and the world. Then, this article will present the financial interdependence that is viewed through the immense debt of the United States to China and its relation to world trade and an analysis of the threats caused by these powers. This article uses the concept of Power and Interdependence as described by Robert O. Keohane and Joseph S. Nye Jr. to be an analytical framework. This research is qualitative research based on case studies, which is reviewed through literature review from related data sources. The findings in this article show that China does indeed have a major influence on the sustainability of the United States and inevitably the two countries must have strong interdependence due to the threats they face.

Keyword: China, United States, Financial, Interdependence 


\section{Pendahuluan}

Dalam beberapa dekade terakhir, Tiongkok menjadi tantangan besar bagi Amerika Serikat. Bangkit melalui reformasi ekonomi pada tahun 1978, Tiongkok perlahan berevolusi sebagai kekuatan ekonomi terbesar kedua di dunia saat ini. Tiongkok secara jelas menunjukkan taring kekuatan ekonominya melalui pertumbuhan pesat Produk Domestik Bruto (PDB) di setiap tahunnya, ekspansi investasi yang semakin meluas, pemasok komoditas utama di dunia, hingga revaluasi progresif Renminbi Yuan. Merujuk terhadap hal tersebut, kekuatan ini menjadi ancaman besar yang terus mengejar kekuatan utama dunia, yaitu Amerika Serikat.

Amerika Serikat secara eksplisit telah menyebutkan kekuatan Tiongkok sebagai tantangan bagi negara tersebut. Di dalam sebuah dokumen pemerintahan, National Security Strategy (NSS) pada tahun 2017, Amerika Serikat secara jelas menuduh Tiongkok sebagai negara kompetitor yang bertujuan untuk menggeser kekuatan Amerika Serikat melalui ambisi perdagangan dan investasi infrastruktur. ${ }^{1}$ Dalam hal ini, dikatakan bahwa Tiongkok telah meningkatkan strategi ekonomi demi membujuk negara lain untuk melancarkan agenda politik dan keamanan negaranya. ${ }^{2}$ Amerika Serikat begitu merespon kekuatan Tiongkok sebagai ancaman yang memberikan eskalasi tensi hubungan kedua negara, dengan kondisi demikian, sistem internasional saat ini begitu diwarnai dengan kompetisi kedua negara great power tersebut.

Sebagai negara dengan kekuatan terbesar di dunia, Amerika Serikat melalui sikap dan kebijakan negaranya begitu percaya diri dalam melawan Tiongkok. ${ }^{3}$ Seperti halnya dalam isu perang dagang. Amerika Serikat secara jelas menantang kebijakan perdagangan Tiongkok dan menyebutkan Tiongkok memberlakukan kebijakan industri dan praktik perdagangan yang tidak adil, seperti dumping serta hambatan non-tarif dan subsidi industri diskriminatif yang merugikan Amerika Serikat.

${ }^{4}$ Terlebih hal demikian mendorong terhadap potensial bentuk perang baru, yaitu perang finansial akibat dari sikap Tiongkok yang melakukan internasionalisasi terhadap nilai Yuan negara tersebut. Merujuk kembali terhadap bentuk perang yang terjadi, patut dikhawatirkan apabila Tiongkok terus menerapkan ekonomi pasar yang semakin terintegrasi maka bukan tidak mungkin posisi ketergantungan finansial dan rantai nilai global dapat beralih dari Amerika Serikat menuju Tiongkok.

Kekhawatiran pengaruh Tiongkok yang begitu berdampak pada struktur global merujuk terhadap ketakutan negara-negara terhadap intervensi Amerika Serikat yang begitu agresif dalam melawan kekuatan ekonomi Tiongkok. Di samping sikap yang begitu ofensif, Amerika Serikat dalam kasus ini kurang menyadari bahwa negara tersebut turut memiliki ketergantungan yang besar terhadap Tiongkok. Hal demikian ditakutkan dapat mengguncang ekonomi Tiongkok yang kemudian berpengaruh besar, tidak hanya pada kestabilan ekonomi dunia, melainkan juga berpengaruh terhadap keamanan dunia.

\footnotetext{
${ }^{1}$ United States Government, National Security Strategy of the United States of America, 2017, 25.

${ }^{2}$ Ibid, 46.

${ }^{3}$ Amerika Serikat saat ini (dalam data terakhir 2019) tercatat sebagai negara dengan Produk Domestik Bruto (PDB) dan Anggaran militer terbesar di dunia. Hal ini ditunjukkan melalui besaran nilai PDB mencapai 87,8 miliar USD dan anggaran militer yang mencapai 732 miliar USD.

4 “President Donald J. Trump is Confronting China's Unfair Trade Policies," May 29, 2018,

https://www.whitehouse.gov/briefings-statements/president-donald-j-trump-confronting-chinas-unfair-trade-policies/.
} 
Patut disadari bahwa kekuatan ekonomi Tiongkok dapat menjadi ancaman bagi kestabilan keamanan dunia. Kekuatan ekonomi yang terus meningkat akan sejalan dengan peningkatan terhadap belanja militer suatu negara. Hal demikian ditunjukkan melalui anggaran militer yang terus meningkat, modernisasi dan akuisisi senjata, serta peningkatan pengaruh nilai terhadap negara mitra. Sementara itu, apabila dibiarkan lebih lanjut kekuatan ini dapat dijadikan sebagai instrumen dan ancaman yang membahayakan. Berdasarkan uraian yang telah dijelaskan sebelumnya, menjadi suatu dilema besar pengaruh Tiongkok terhadap ekonomi dan keamanan dunia. Apabila kekuatan ekonomi Tiongkok dilemahkan, hal ini berdampak signifikan terhadap perekonomian Amerika Serikat dan dunia secara keseluruhan. Namun, disisi lain apabila dibiarkan terus berkembang, akan menjadi ancaman bagi stabilitas keamanan dunia.

Untuk menyikapi hal tersebut, Amerika Serikat sebagai negara potensial memiliki andil besar dalam merespon dilema kekuatan Tiongkok. Untuk itu penting ditelaah bagaimana pengaruh finansial dan ekonomi Tiongkok dapat menjadi ancaman bagi Amerika Serikat dan dunia. Artikel ini akan terlebih dahulu menguraikan ketergantungan Amerika Serikat dalam aspek ekonomi dan finansial beserta ancaman yang terjadi sehingga pada akhirnya menentukan pola hubungan kedua negara tersebut.

\section{Kajian Literatur}

Berbicara terkait pola hubungan Amerika Serikat dan Tiongkok identik digambarkan sebagai kemitraan yang didasari atas kurangnya kepercayaan bersama (mutual distrust). Lieberthal dan Jisi (2012) mengutarakan kenyataan yang terjadi antara hubungan kedua negara digambarkan begitu korosif. Merefleksi kembali terhadap sejarah dan aktivitas ekstensif Amerika Serikat dan Tiongkok, sulitnya kepercayaan strategis kedua negara mendasar pada perbedaan dalam sistem dan nilai politik serta keraguan penggunaan kekuatan negara. Selain itu, ketidakmampuan untuk memahami negara satu sama lain semakin memperburuk terwujudnya kepercayaan strategis yang dijangkau dalam jangka panjang. ${ }^{5}$

Merespon terhadap Lieberthal dan Jisi (2012), Friedman (2013), mengutarakan bahwa permasalahan dalam hubungan Amerika Serikat dan Tiongkok memang didasari atas ketidakpercayaan satu sama lain. Friedman mengutarakan bahwa terdapat fakta yang tidak dapat disingkirkan terkait dengan benturan kepentingan vital yang dapat membawa kedua negara pada arah konflik bersenjata. ${ }^{6}$ Friedman juga menggambarkan gerakan kedua negara telah meningkatkan tensi dilema keamanan yang semakin tidak beralasan dan berpotensi berbahaya bagi stabilitas keamanan internasional. Sebagai bentuk upaya dalam membangun kepentingan bersama, Friedman menekankan pentingnya dibentuk kepentingan yang diinstitusikan secara bersama agar meminimalisir ancaman negara. Namun, apakah kepentingan yang diinstitusikan dapat membuahkan resolusi yang baik bagi hubungan kedua negara?

Sebelum mengarah terhadap kepentingan bersama yang diinstitusikan, perlu dipahami bahwa terdapat perbedaan mendasar dari latar belakang dibentuknya kepentingan masing-masing negara. Elliott (2017) menggambarkan Amerika Serikat dan Tiongkok berada dalam dua arah kepentingan

\footnotetext{
${ }^{5}$ Kenneth Lieberthal and Wang Jisi, “Addresing U.S.- China Strategic Distrust,” John L. Thornton China Center Monograph Series, no. 4 (2012): 34.

${ }^{6}$ Edward Friedman, "Building New Vital Mutual Interests for a Better Future: A Commentary on Wang Jisi and Kenneth Lieberthal's Addressing US-China Strategic Distrust," Journal of Contemporary China 22, no. 81 (2013): 369-70, https://doi.org/10.1080/10670564.2012.748957.
} 
yang berbeda. Amerika Serikat memiliki fokus pada perubahan peraturan pasca krisis 2008 silam dan mencari biaya atau manfaat yang sesuai dengan pertumbuhan ekonomi, sedangkan Tiongkok memiliki fokus pada kombinasi dari tantangan dan peluang pada pertumbuhan sistem keuangan yang mencerminkan kebangkitan negara secara keseluruhan serta pertumbuhan pasar sektor swasta. ${ }^{7}$ Kedua pandangan yang berlawanan tersebut mengarahkan pada sulitnya menyatukan kepentingan bersama yang turut memengaruhi terhadap keberlanjutan hubungan negara.

Namun, terdapat sebuah pendekatan berbeda dalam menyikapi sulitnya menyatukan hubungan kedua negara. Amerika Serikat dan Tiongkok secara strategis menyadari bahwa kedua negara tersebut memiliki pengaruh besar satu sama lain, sehingga keduanya menyadari pentingnya mengatur hubungan bilateral yang dikhususkan dalam konteks tujuan ekonomi. Hal demikian didukung oleh seorang peneliti, Hang (2016) mengutarakan bahwa meskipun Amerika Serikat begitu menyadari prioritas kompetisi global dalam melawan ekonomi Tiongkok, tetapi negara tersebut tetap menyadari adanya ikatan ekonomi yang kuat dapat menguntungkan kedua belah pihak. ${ }^{8}$ Saling ketergantungan ekonomi yang ditumbuhkan kedua negara menjadi alasan bahwa di tengah anarkinya sistem internasional, negara masih membutuhkan negara lainnya untuk tetap bertahan hidup memenuhi kepentingan nasionalnya.

Menyoroti terhadap hal tersebut, artikel ini meyakini bahwa di samping hubungan yang begitu korosif, Amerika Serikat dan Tiongkok tetap memerlukan sebuah langkah strategis melalui strategi interdependensi. Hal ini berbeda dari penelitian-penelitian sebelumnya yang lebih condong membahas tantangan, perbedaan kepentingan, dan kompetisi global hingga mengakibatkan terbentuknya hubungan korosif antara Amerika Serikat dan Tiongkok. Artikel ini akan memberikan fokus pada sikap kedua negara yang mengupayakan hubungan ekonomi bilateral sebagai jawaban atas penghindaran ancaman ekonomi dan keamanan yang terjadi.

\section{Metode Penelitian}

Dalam artikel ini, penulis menggunakan metode studi kasus dengan pendekatan kualitatif deskriptif untuk menganalisis fenomena terkait. Menurut Yves-Chantal Gagnon, metode studi kasus adalah metode yang digunakan untuk mengamati dan menganalisis suatu fenomena secara menyeluruh yang dapat menghasilkan deskripsi rinci dan pemahaman mendalam mengenai perasaan dan interaksi aktor-aktor terlibat. ${ }^{9}$ Lebih lanjut, artikel ini juga merujuk pada Robert K. Yin yang melibatkan model metode studi kasus, Multiple Case Design, untuk mendapatkan gambaran kompleksitas fenomena yang lebih komprehensif. ${ }^{10}$

Perolehan sumber kualitatif dalam penelitian ini dilakukan dengan cara mengumpulkan literatur yang bersumber dari buku, jurnal, dokumen negara, dan sumber digital. Pengumpulan data tersebut selanjutnya ditelaah dan dikaitkan dengan konsep relevan, yaitu power dan interdependensi sebagai kerangka berpikir analisis. Hasil analisis data dari studi literatur dan pembahasan merupakan indikator utama perumusan masalah yang menjadi kesimpulan dalam fenomena tersebut.

\footnotetext{
${ }^{7}$ Douglass J. Elliott, "Living in Two Worlds: Chinese and U.S. Financial Regulation,” Living in Two Worlds: Chinese and U.S. Financial Regulation, Center for Strategic and International Studies, September 22, 2017, https://www.csis.org/livingtwo-worlds-chinese-and-us-financial-regulation.

${ }^{8}$ Nguyen Thi Thuy Hang, “The United States and China: Can They Cooperate?," Asian Affairs(UK) 43, no. 3 (2016): 73 , https://doi.org/10.1080/00927678.2016.1200332.

${ }^{9}$ Umar Suryadi Bakry, Metode Penelitian Hubungan Internasional, Yogyakarta: Pustaka Pelajar, 2017, 223.

${ }^{10}$ Robert K. Yin, Case Study Research: Design and Methods, Thousand Oaks: Sage Publications, 2014, 47-53.
} 


\section{Kerangka Teori}

Dalam menganalisis hubungan Amerika Serikat dan Tiongkok diperlukan analisis pada teori dasar yang memandang tindakan negara. Dalam studi Hubungan Internasional, terdapat paradigma besar yang dapat menggambarkan hal tersebut, yaitu Liberalisme. Liberalisme tersebut memberikan asumsi terhadap tindakan negara yang didasari atas tindakan rasional. Berbeda dengan Realis yang menggambarkan sikap rasional negara ditinjau melalui perolehan sumber daya kekuatan (power) negara, khususnya kekuatan militer, Liberalisme menguraikan tindakan rasional negara melalui kerja sama serta mengusungkan kepentingan ekonomi insentif pada fokus perhatian lainnya, selain dari aspek keamanan. ${ }^{11}$

Tinjauan terhadap paradigma tersebut, mengerucut terhadap dua konsep yang menjadi alat analisis dalam artikel ini, yaitu konsep Power dan Interdependence. Robert O. Keohane dan Joseph S. Nye (1973) berupaya untuk mengaitkan kedua konsep tersebut dengan mengeksplorasi peran kekuatan negara dalam interdependensi di sistem internasional. Secara definitif, power mengacu terhadap kemampuan aktor memengaruhi aktor lainnya dalam menghasilkan suatu hasil tertentu.

Sementara itu, interdependensi menurut Keohane dan Nye (1973) dibagi ke dalam dua dimensi besar, yaitu interdependensi dalam aspek sensitivitas dan kerentanan. Interdependensi sensitivitas dijelaskan sebagai tindakan responsif negara yang dapat membawa pengaruh terhadap negara lainnya, sedangkan dalam aspek kerentanan diidentifikasikan sebagai bentuk saling ketergantungan yang bergantung terhadap biaya kerentanan relatif yang mana semakin berkurangnya ketergantungan negara menyebabkan rendahnya biaya relatif yang harus dikeluarkan. ${ }^{12}$

Merujuk terhadap dua dimensi interdependensi, kedua hal tersebut memiliki kaitan dalam penentuan aktor yang memiliki kuasa lebih untuk menentukan aturan main dalam hubungan interdependensi kedua negara. Keohane dan Nye (1973) kemudian menggambarkan fenomena interdependensi berikut ke dalam bentuk interdependensi asimetris dengan tinjauan simetris yang diukur berdasarkan kekuatan (power) suatu negara dalam kemampuannya untuk mengatur tingkat interdependensi negara dengan negara lainnya. Mengutip dalam penelitian selanjutnya, Keohane dan Nye (1987) menganalisis orientasi kekuatan dalam interdependensi yang digambarkan melalui bargaining theory (teori tawar menawar).

Apabila dikaitkan dalam konteks hubungan Amerika Serikat dan Tiongkok secara bilateral, dapat dikatakan bahwa adanya interdependensi asimetris dapat menjadi sumber kekuatan dalam hubungan bilateral kedua negara melalui suatu proses bargaining. Penerapan aturan tawar-menawar antara kedua negara berkekuatan besar ini memberikan peluang, tidak hanya dalam kerja sama yang singkat melainkan dalam jangka panjang. Hal demikian disebabkan oleh biaya relatif yang harus diperhitungkan oleh suatu negara saat melepaskan ketergantungan terhadap negara lainnya.

\section{Interdependensi Finansial Amerika Serikat-Tiongkok}

Saat ini sistem internasional diwarnai oleh persaingan Amerika Serikat dan Tiongkok yang begitu kompetitif. Namun, faktanya terdapat tindakan strategis yang memberikan celah peluang ketergantungan kedua negara yang ditinjau melalui ketergantungan finansial dan ekonomi kedua negara berkekuatan besar tersebut. Dalam aspek finansial, artikel ini memfokuskan terhadap analisis

\footnotetext{
${ }^{11}$ Robert O. Keohane and Joseph S. Nye, "Power and Interdependence Revisited," International Organization 41, no. 4 (1987): 729.

${ }^{12}$ Robert O. Keohane and Joseph S. Nye, "Power and Interdependence," Survival: Global Politics and Strategy 15, no. 4 (1973): 60, https://doi.org/http://dx.doi.org/10.1080/00396337308441409.
} 
utang Amerika Serikat yang dimiliki oleh Tiongkok Selanjutnya, tinjauan tersebut berkaitan dengan aspek ekonomi yang diilustrasikan melalui hubungan perdagangan kedua negara.

Sebagai negara dengan perolehan Produk Domestik Bruto (PDB) terbesar di dunia serta donatur utama dalam berbagai institusi finansial internasional, hal tersebut tidak menjadikan Amerika Serikat terlepas dari utang negara. Untuk memenuhi kebutuhan negaranya, Amerika Serikat perlu memaksimalkan anggaran negara dengan melakukan penambahan aset negara melalui utangnya terhadap pihak lain. Tinjauan utang Amerika Serikat diatur melalui lembaga keuangan, US Department of the Treasury yang dapat dibagi kedalam dua kategori, yaitu intragovernmental holdings dan public debt. intragovernmental holdings adalah kepemilikan utang intra-pemerintahan yang terdiri dari dana perwakilan pemerintahan, dana bergulir dan dana khusus. ${ }^{13}$ Sementara itu, public debt mengacu terhadap seluruh utang pemerintahan federal yang berasal dari individu, korporasi, negara dan pemerintahan lokal, pemerintahan luar negeri, dan lainnya. ${ }^{14}$ Tercatat melalui US Department of the Treasury, utang Amerika Serikat pada kuartal kedua 2020, melalui kedua tinjauan utang tersebut telah mencapai sekitar 26,47 triliun USD atau setara dengan 136\% dari PDB negara tersebut. ${ }^{1516}$

Dalam menganalisis utang Amerika Serikat, artikel ini memberikan fokus utama terhadap public debt, hal tersebut dikarenakan public debt memiliki jumlah sebesar 77\% dari keseluruhan utang negara serta memiliki korelasi terhadap utangnya dengan Tiongkok. ${ }^{17}$ Dalam menyokong anggaran negara, Amerika Serikat memerlukan pinjaman dari utang publik dengan skema penerbitan obligasi yang dikeluarkan oleh US Department of the Treasury Department. Produk obligasi tersebut kemudian dimanfaatkan untuk membiayai beban defisit anggaran serta menjaga sirkulasi ekonomi Amerika Serikat. ${ }^{18}$ Untuk memahami utang publik Amerika Serikat, berikut adalah gambaran terkait kepemilikan surat obligasi yang ditinjau berdasarkan sepuluh negara utama.

\footnotetext{
13 "Intragovernmental Holdings and Debt Held by the Public," Treasury Direct, October 5, 2020, https://www.treasurydirect.gov/govt/charts/principal/principal_govpub.htm.

${ }^{14} \mathrm{Ibid}$

15 "Debt to the Penny," FiscalData.Treasury.gov, October 30, 2020, https://fiscaldata.treasury.gov/datasets/debt-to-thepenny/debt-to-the-penny.

${ }^{16}$ Melalui data US Department of Commerce, PDB Amerika Serikat dalam data terakhir (Q2 2020) ialah sebesar 19.520, 1 miliar USD. https://apps.bea.gov/iTable/iTable.cfm?reqid=19\&step=3\&isuri=1\&nipa_table_list=5\&categories=survey 17 Kimberly Amadeo, "Who Owns the US National Debt?" The Balance, October 14, 2020, https://www.thebalance.com/who-owns-the-u-s-national-debt-3306124.https://www.thebalance.com/who-owns-the-u-snational-debt-3306124\#citation-10.

18 “National Debt," Investopedia, September 23, 2020, https://www.investopedia.com/updates/usa-national-debt/.
} 


\section{Major Foreign Holders Of Treasury Securities Q2 2020 (In Billions Of USD)}

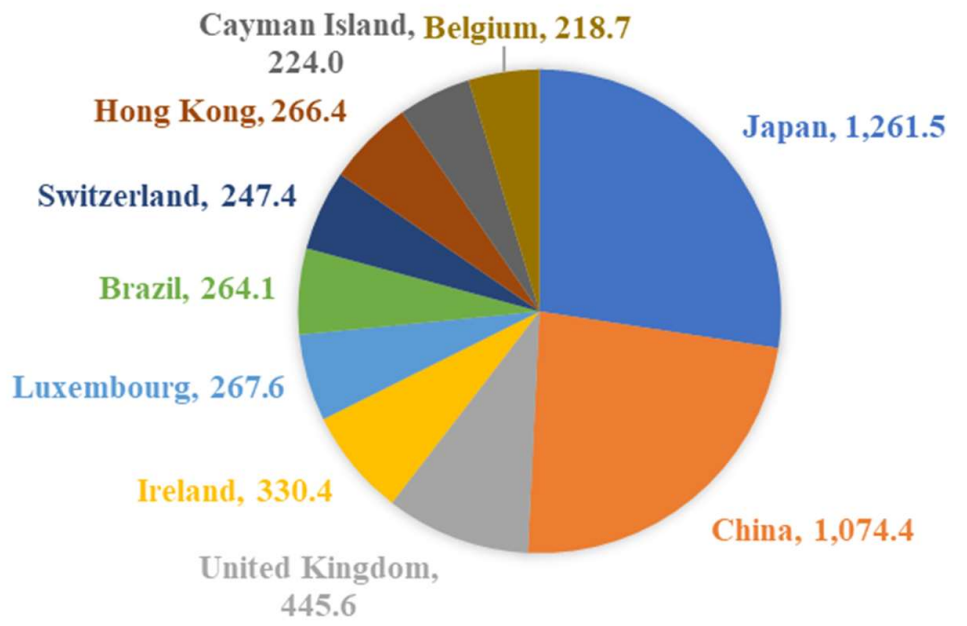

Gambar 1. Major Foreign Holders of Treasury

Sumber: US Department of the Treasury, 2020

Gambar 1 mengilustrasikan sepuluh negara dengan nilai terbesar dalam kepemilikan obligasi berdasarkan data Juni 2020 (akhir kuartal 2, tahun 2020). Berdasarkan gambar tersebut, posisi pertama diduduki oleh Jepang, dengan besaran mencapai 1.261,5 miliar USD yang kemudian dilanjutkan dengan Tiongkok sebesar 1.074,4 miliar USD. Dalam gambar tersebut juga dapat dilihat terdapat celah yang cukup jauh dari nilai kepemilikan obligasi negara-negara di bawahnya. Dengan demikian dapat dikatakan bahwa utang Amerika Serikat bergantung besar terhadap Jepang dan Tiongkok sebagai pemberi utang utama.

Besarnya utang terhadap Jepang bukanlah menjadi fokus utama analisis utang Amerika Serikat dalam artikel ini. Pasalnya, Jepang merupakan negara mitra Amerika Serikat yang tidak menjadi ancaman utama bagi negara. Sementara itu, tinjauan utang terhadap Tiongkok dianggap lebih berbahaya akibat implikasinya terhadap nilai tukar mata uang dan juga perdagangan kedua negara. Untuk menganalisis hal tersebut, pertama perlu diketahui alasan Tiongkok membeli utang Amerika Serikat. Alasan pertama diawali dengan alasan historis terkait krisis finansial Asia pada tahun 1997 yang begitu melumpuhkan ekonomi Asia, terutama Tiongkok. Dalam upayanya untuk bangkit dari kelumpuhan pasca krisis serta menciptakan jaring pengaman baru, Tiongkok melakukan pembelian utang Amerika Serikat dengan tujuan mendapatkan cadangan devisa yang lebih besar sehingga dapat menjaga kestabilan ekonomi domestik. ${ }^{19}$

Alasan selanjutnya diimbangi dengan perspektif sistem finansial yang memang begitu kompleks. Hal ini berkaitan dengan keharusan sebuah negara untuk melakukan pembelian aset asing untuk mencegah terjadinya inflasi. Di dalam kasus ini, untuk menghindari inflasi, bank sentral Tiongkok harus mengurangi masuknya mata uang asing dengan cara membeli obligasi Amerika Serikat serta melakukan penyesuaian terhadap mata uang yang kemudian berkaitan terhadap

\footnotetext{
19“'Is it a Risk for America that China Holds over \$1 Trillion in U.S. Debt?" Center for Strategic and International Studies, accessed October 27, 2020, https://chinapower.csis.org/us-debt/.
} 
perdagangan negara. ${ }^{20}$ Berkaitan dengan hal tersebut, perlu dipahami bahwa sasaran pembelian obligasi Amerika Serikat juga didasari pada minimnya risiko kestabilan dan keamanan investasi negara dibandingkan instrumen investasi lainnya.

Keunggulan pembelian obligasi Amerika Serikat juga ditinjau melalui peluang Tiongkok dalam melakukan transisi mata uang Yuan ke mata uang global. Saat ini, tren perekonomian Tiongkok ditunjang melalui kekuatan perdagangan negara, yang dilihat dari besaran ekspor dan impor negara tersebut. Dalam sistem perdagangan internasional, Dolar Amerika Serikat menjadi tolak ukur ekspor dan impor komoditas perdagangan. Menyadari hal tersebut, sebagai negara dengan tumpuan utama sektor perdagangan, Tiongkok harus menjaga nilai Yuan agar tetap stabil. Mengapa demikian?

Ketika Tiongkok banyak melakukan transaksi ekspor maka negara tersebut akan menerima nilai Dolar dalam jumlah yang banyak. Sementara itu, Tiongkok tetap membutuhkan mata uang Yuan untuk aktivitas ekonomi dalam negeri. Dengan kata lain, Tiongkok harus menjual Dolar tersebut yang mengakibatkan mata uang Dolar terdepresiasi dan Yuan terapresiasi. Namun, jika mata uang Yuan terus terapresiasi maka ekspor Tiongkok menjadi menurun akibat dari naiknya harga komoditas. Untuk itu, Tiongkok melakukan pembelian terhadap surat utang Amerika Serikat agar mata uang Yuan yang beredar di pasar meningkat serta mengakibatkan ekspor negara tersebut tetap terjaga. Uraian tersebut dibuktikan melalui tinjauan perdagangan Amerika Serikat dan Tiongkok sebagai berikut.

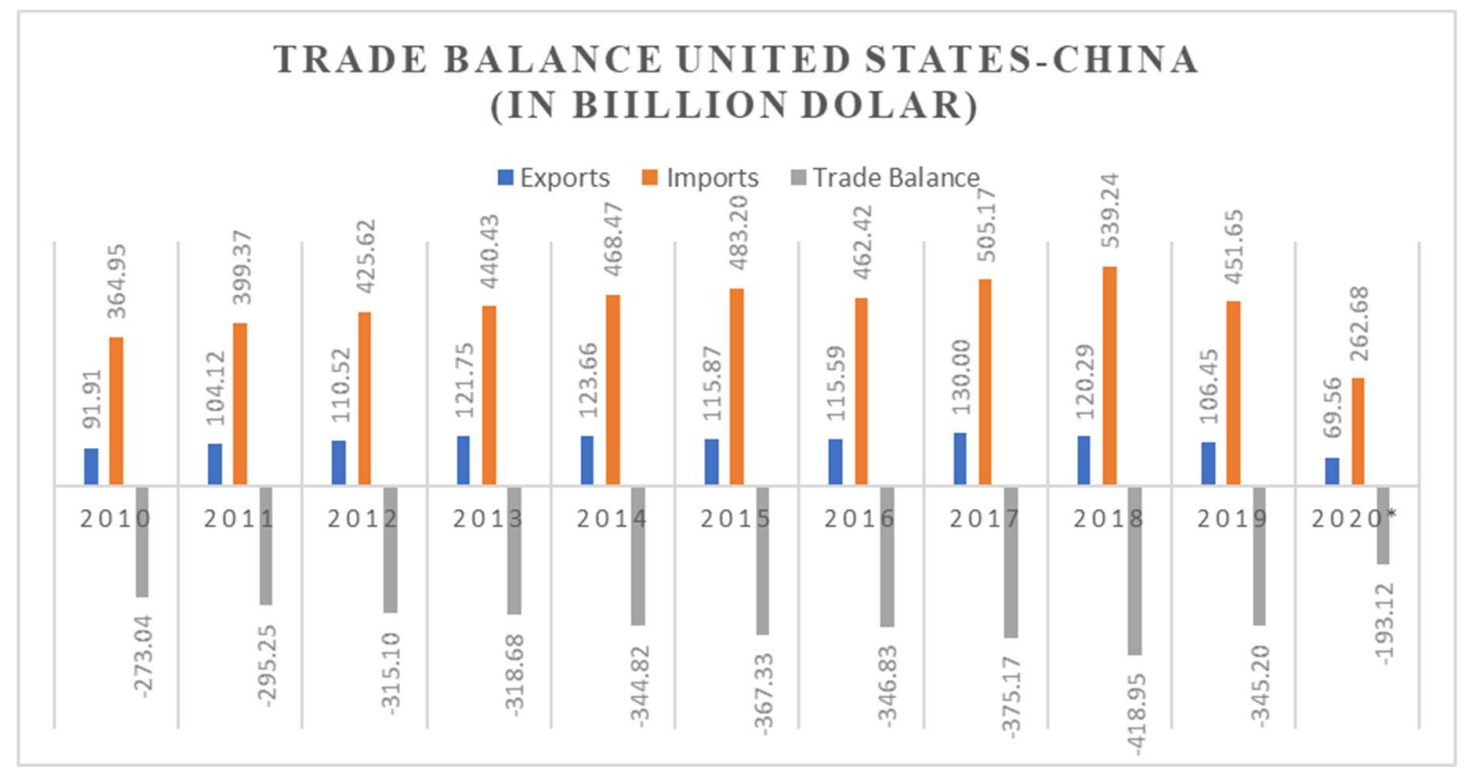

\section{Gambar 2. Trade Balance United States and China}

Sumber: United States Census of Bureau, 2020

Gambar 2 mengilustrasikan neraca perdagangan Amerika Serikat dan Tiongkok dari periode 2010-2020. Berdasarkan gambar tersebut, Amerika Serikat selalu dihadapkan dengan defisit perdagangan terhadap Tiongkok akibat dari besarnya nilai impor Tiongkok yang lebih tinggi dibandingkan ekspor Amerika Serikat setiap tahunnya. Hal demikian membuktikan bahwa kepemilikan utang Amerika Serikat telah membantu pertumbuhan ekonomi Tiongkok dan berdampak negatif bagi Amerika Serikat.

${ }^{20}$ Ibid. 
Merespon hal tersebut, Amerika Serikat dibawah pemerintahan Trump telah memberlakukan hukuman terhadap Tiongkok berupa kenaikan tarif dan pembatasan investasi pada komoditas maupun perusahaan Tiongkok. ${ }^{21}$ Trump juga tidak segan mengkritik perdagangan Tiongkok yang dianggap hanya mengambil keuntungan dari perekonomian Amerika Serikat saja. ${ }^{22}$ Namun, sikap Trump yang begitu agresif dalam menyikapi Tiongkok tersebut melahirkan kekhawatiran tersendiri. Pasalnya, Tiongkok memegang kendali cukup besar dalam utang Amerika Serikat. Apabila Tiongkok merespon "kekejaman" hukuman yang diberikan Trump melalui penjualan utang Amerika Serikat dalam jumlah yang besar, hal tersebut mengakibatkan pelemahan dari nilai Dolar yang berakibat sangat signifikan terhadap ekonomi Amerika Serikat, terlebih melihat tren Tiongkok yang semakin melakukan internasionalisasi terhadap mata uangnya.

\section{Kekuatan Ekonomi Tiongkok}

Memanasnya hubungan Amerika Serikat dengan Tiongkok dimulai sejak pertumbuhan ekonomi Tiongkok yang begitu pesat. Bangkit dari keterpurukan inefisiensi sistem ekonomi tradisionalnya, Tiongkok melakukan reformasi dengan menyerap sistem ekonomi liberal yang memperkenalkan bisnis swasta dan insentif pasar. Reformasi Tiongkok kemudian membawa kontribusi besar terhadap pertumbuhan ekonomi negara yang ditunjukkan dengan besaran angka pertumbuhan PDB rata-rata hampir 10 persen per tahun dan lebih dari 850 juta orang telah berhasil keluar dari garis kemiskinan di negara tersebut. ${ }^{23}$ Berkat warisan ide yang dibawakan melalui reformasi, Tiongkok saat ini digolongkan sebagai upper-middle-income country dan negara dengan kekuatan ekonomi terbesar kedua di dunia.

Kebangkitan Tiongkok diikuti dengan langkah strategis negara dalam membentuk pengaruh besar dunia. Dalam tindakan strategisnya, Tiongkok mempersiapkan strategi yang bertujuan untuk menciptakan kestabilan sistem moneter internasional untuk perkembangan ekonominya sendiri. ${ }^{24}$ Berkaitan dengan hal tersebut, Tiongkok melakukan internasionalisasi terhadap mata uangnya agar perdagangan, pinjaman, dan investasi internasional dapat menggunakan Renminbi Yuan. ${ }^{25}$ Langkah strategis juga dilakukan dengan cara menciptakan inisiasi kebijakan Belt and Road Initiative (BRI) yang kemudian melahirkan pertumbuhan ekonomi secara masif melalui ekspansi investasi luar negeri (FDI) yang semakin meningkat.

Dari aspek perdagangan, transaksi ekspor-impor menjadi tinjauan utama dalam perekonomian Tiongkok dengan peranan pentingnya sebagai pemasok utama sektor manufaktur di luar negeri, ditunjukan dengan sekitar $20 \%$ perdagangan global dalam produk manufaktur berasal dari Tiongkok. ${ }^{26}$ Bahkan di tengah sulitnya perekonomian terdampak COVID-19 saat ini, Tiongkok diprediksi menjadi

\footnotetext{
${ }^{21}$ Wang Jisi and Hu Ran, "From Cooperative Partnership to Strategic Competition: A Review of China-U.S. Relations 20092019," China International Strategy Review 1, no. 1 (2019): 4, https://doi.org/10.1007/s42533- 019-00007-w.

${ }_{22}^{2}$ Ibid, United States Government, National Security Strategy of the United States of America, 2017.

${ }^{23}$ The World Bank, China Overview, accessed October 27, 2020, https://www.worldbank.org/en/country/china/overview\#1.

${ }^{24}$ Edwin L. and C. Lal, "Renminbi Internationalization: The Prospects of China's Yuan as the Next Global Currency," The

Hong Kong University of Science and Technology, June 2015, https://iems.ust.hk/publications/thought-leadership-

briefs/renminbi-internationalization-the-prospects-of-chinas-yuan-as-the-next-global-

currency\#: :text=Internationalization\%20of\%20the\%20renminbi\%20(RMB,\%2C\%20borrowing\%2C\%20and\%20investing

$\% 20$ internationally.

${ }^{25}$ Ibid.

${ }^{26}$ United Nations Conference on Trade and Development (UNCTAD), Global Trade Impact of The Coronavirus (COVID-

19) Epidemic, March 4, 2020.
} 
satu-satunya ekonomi di dunia yang menunjukkan pertumbuhan positif pada tahun $2020{ }^{27}$ Berdasarkan uraian tersebut, apabila pertumbuhan ekonomi Tiongkok dibandingkan dengan Amerika Serikat maka dapat digambarkan sebagai berikut.

Tabel 1. Gross Domestic Product Growth and Projections

\begin{tabular}{|c|c|c|c|c|}
\hline \multicolumn{2}{|c|}{ Year } & United States & China & World \\
\hline \multicolumn{2}{|l|}{$2002-2011$} & 1.8 & 10.7 & 4.1 \\
\hline \multicolumn{2}{|l|}{2012} & 2.2 & 7.9 & 3.5 \\
\hline \multicolumn{2}{|l|}{2013} & 1.8 & 7.8 & 3.5 \\
\hline \multicolumn{2}{|l|}{2014} & 2.5 & 7.3 & 3.5 \\
\hline \multicolumn{2}{|l|}{2015} & 3.1 & 6.9 & 3.4 \\
\hline \multicolumn{2}{|l|}{2016} & 1.7 & 6.8 & 3.3 \\
\hline \multicolumn{2}{|l|}{2017} & 2.3 & 6.9 & 3.8 \\
\hline \multicolumn{2}{|l|}{2018} & 3 & 6.7 & 3.5 \\
\hline \multicolumn{2}{|l|}{2019} & 2.2 & 6.1 & 2.8 \\
\hline \multirow[t]{3}{*}{ Projections* } & 2020 & -5.8 & 1.9 & -4.4 \\
\hline & 2021 & 3.9 & 8.2 & 5.2 \\
\hline & 2025 & 1.7 & 5.5 & 3.5 \\
\hline
\end{tabular}

Sumber: International Monetary Fund, 2020

Berdasarkan Tabel 1, secara garis besar dapat dilihat bahwa pertumbuhan PDB Tiongkok memiliki persentase yang jauh mengungguli Amerika Serikat. Bahkan sejak tahun 2002 hingga 2019 pertumbuhan ekonomi Amerika Serikat menunjukkan besaran rata-rata sekitar 2,04\% berbeda dengan Tiongkok yang tumbuh pesat sekitar $9,10 \%$. Tidak hanya demikian, dalam menghadapi sulitnya pandemi seperti saat ini pun Tiongkok diprediksi mengalami pertumbuhan positif dalam PDBnya dengan besaran sekitar $1,9 \%$ dan mencapai $8,2 \%$ pada tahun 2021. Hal tersebut berbeda signifikan apabila meninjau PDB Amerika Serikat yang mengalami kontraksi sebesar 4,3\% pada tahun 2020.

\section{Ancaman Keamanan dalam Kekuatan Strategis Tiongkok}

Tumbuh sebagai negara dengan pengaruh besar dalam aspek ekonomi memberikan peluang bagi Tiongkok dalam mengembangkan kekuatan ekonominya menjadi kekuatan militer. Dalam beberapa tahun terakhir, Tiongkok telah menghabiskan triliunan Yuan untuk anggaran militer demi melakukan modernisasi militer untuk mengimbangi kekuatan militer negara rivalnya. Kekuatan militer tersebut tercermin dalam perolehan negara mencapai kekuatan kedua dengan besarnya anggaran belanja militer. Tren belanja militer Tiongkok secara jelas akan diilustrasikan melalui gambar berikut.

27 "China to be the only economy with positive growth in 2020, says IMF report," CGTN, October 19, 2020, https://news.cgtn.com/news/2020-10-13/World-GDP-to-drop-4-4-in-2020-IMF--UyNuoUIFlC/index.html 


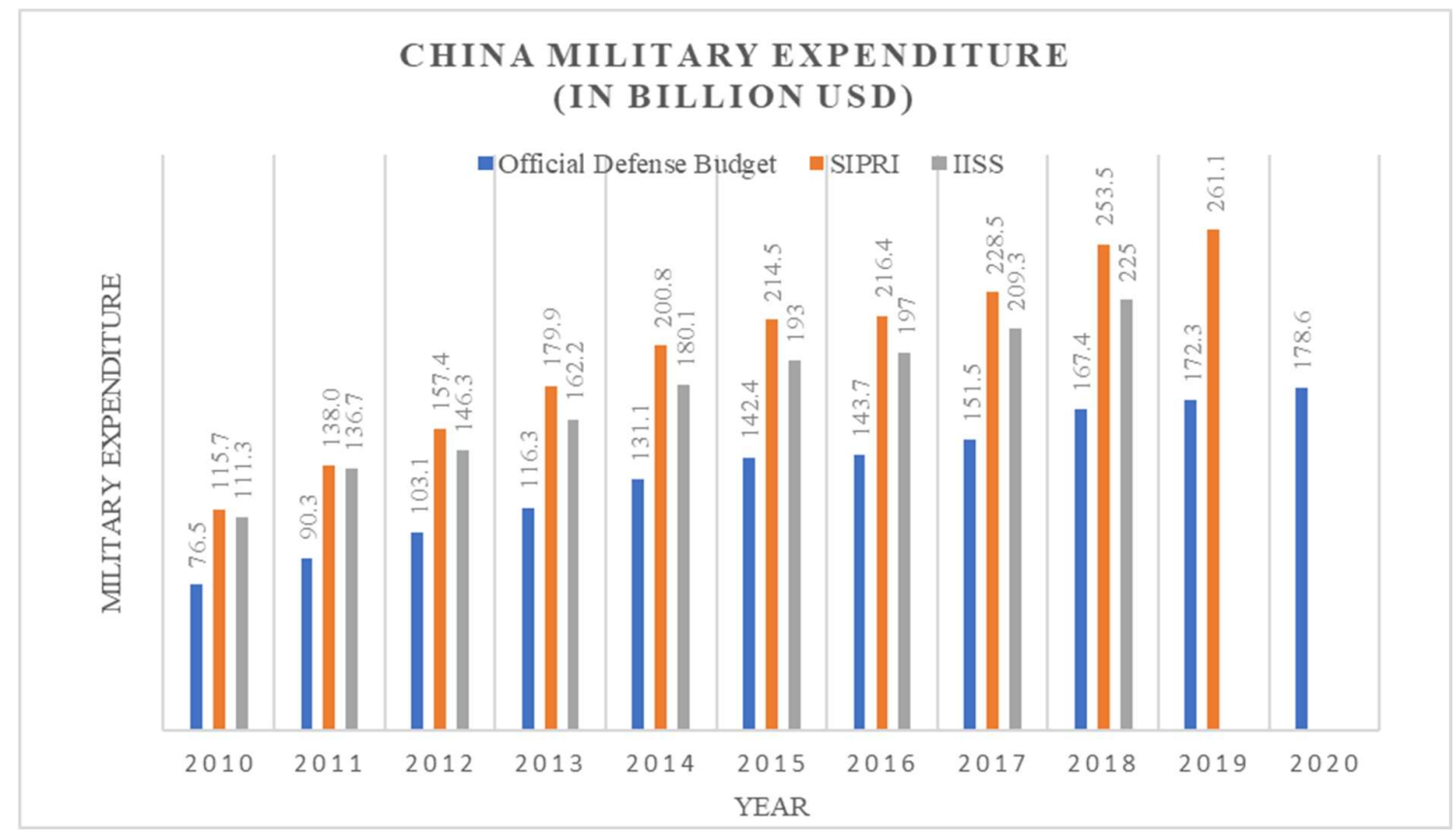

Gambar 3 China Military Expenditure

Sumber: CSIS, 2020

Berdasarkan Gambar 3, secara periodical, anggaran militer Tiongkok mengalami tren peningkatan terus menerus sejak periode 2010-2020. Dalam laporan resminya, pada tahun 2020 capaian anggaran belanja militer Tiongkok mencapai sekitar 178,6 miliar USD. Namun, apabila melihat kembali pada gambar tersebut, dalam riset penelitian yang dilakukan oleh Stockholm International Peace Research Institute (SIPRI) dan International Institute for Strategic Studies (IISS), besarnya anggaran pengeluaran militer yang dikeluarkan secara resmi dalam periode tersebut didapati signifikan berbeda pada realitanya.

Perbedaan aktual tersebut didasari atas kurangnya transparansi Tiongkok dalam memberikan laporan resmi belanja militernya. Besaran angka yang secara resmi dikeluarkan Tiongkok tidak memperhitungkan sejumlah pengeluaran terkait militer lainnya, seperti anggaran dalam program ruang angkasa, pendapatan ekstra anggaran dari perusahaan komersial militer, dana mobilisasi pertahanan, biaya operasi pangkalan militer provinsi, serta berbagai ekstra anggaran lainnya yang seharusnya tercatat secara resmi dalam anggaran belanja militer. ${ }^{28}$ Selain itu, Tiongkok juga tidak menguraikan besaran pengeluaran dalam aspek keamanan publik. Berkaitan dengan hal tersebut, anggaran sebesar RMB 179,78 miliar atau setara dengan 26,8 miliar USD yang dikhususkan untuk the People's Armed Police (PAP) merupakan salah satu contoh besarnya anggaran yang tidak dituliskan dalam pengeluaran resmi militer negara. ${ }^{2930}$

\footnotetext{
28 "What Does China Really Spend on its Military?" Center for Strategic and International Studies, accessed October 27, 2020, https://chinapower.csis.org/military-spending/\#easy-footnote-bottom-4-142.

${ }^{29}$ Ibid.

${ }^{30}$ The People's Armed Police (PAP) adalah komponen polisi paramiliter dari angkatan bersenjata Tiongkok yang bertanggung jawab atas keamanan internal, penegakan hukum, dan perlindungan hak maritim.
} 
Secara garis besar meningkatnya anggaran militer Tiongkok ditujukan untuk melakukan pengembangan dan modernisasi terhadap instrumen militernya, yaitu personel, pelatihan dan pemeliharaan, serta peralatan. Dalam laporan resmi belanja militer pada tahun 2017, alokasi pembelanjaan digambarkan melalui tabel berikut.

Tabel 2. Breakdown of China's Military Expenditure (in Billion USD)

\begin{tabular}{|c|c|c|c|c|c|}
\hline & \multirow{2}{*}{$\begin{array}{l}\text { Active } \\
\text { Forces }\end{array}$} & \multirow{2}{*}{$\begin{array}{l}\text { Reserve } \\
\text { Forces }\end{array}$} & \multirow{2}{*}{$\begin{array}{l}\text { Militia } \\
\text { and Others }\end{array}$} & \multicolumn{2}{|c|}{ Total } \\
\hline & & & & Amount & Percentage \\
\hline Personnel & 47.04 & 0.48 & 0.00 & 47.51 & $30.77 \%$ \\
\hline $\begin{array}{l}\text { Training } \\
\text { \& Maintenance }\end{array}$ & 39.76 & 0.69 & 2.97 & 43.41 & $28.12 \%$ \\
\hline Equipment & 62.79 & 0.63 & 0.04 & 63.47 & $41.11 \%$ \\
\hline Total & 149.59 & 1.80 & 3.01 & 154.39 & $100.00 \%$ \\
\hline
\end{tabular}

Sumber: CSIS, 2020

Berdasarkan Tabel 2, alokasi pembelanjaan terhadap peralatan memperoleh kedudukan persentase yang terbesar, yaitu sebesar $41,1 \%$. Hal demikian terbukti dengan keberhasilan Tiongkok menduduki posisi terbesar kedua sebagai produsen amunisi senjata terbesar di dunia, perubahan ini sangat terlihat secara jelas setelah satu dekade sebelumnya Tiongkok hanya mengandalkan impor dalam peralatan senjatanya. $^{31}$ Sejalan dengan peningkatan kemampuan produksi senjata, Tiongkok mampu memberikan kekhawatiran pada risiko proliferasi senjata akibat dari belum banyaknya negara tersebut dalam menandatangani peraturan pengendalian senjata, ${ }^{32}$

Dalam tinjauan berikutnya, alokasi anggaran militer Tiongkok kedua terbesar ditujukan untuk personel militernya, ditunjukkan melalui alokasi anggaran personel yang mencapai 30,8\% dari keseluruhan anggaran militernya. Pencapaian tersebut ditunjukkan pada keberhasilan Tiongkok meraih kedudukan pertama di dunia dalam jumlah personel militer dengan sekitar 2,1 juta tentara aktif sehingga Tiongkok harus mengeluarkan ekstra pengeluaran yang ditujukan untuk mendukung kesejahteraan personel militernya. ${ }^{33}$ Tinjauan terakhir dapat dilihat melalui alokasi anggaran pada program pelatihan dan pemeliharaan, yaitu sebesar $28,1 \%$ dari keseluruhan anggaran militer. Hal tersebut ditunjukan melalui pelatihan personel yang bertujuan untuk mendukung pembangunan ekonomi nasional, upaya penyelamatan darurat, serta bantuan bencana. ${ }^{34}$

Melihat kembali pada anggaran militer Tiongkok yang diilustrasikan pada Gambar 2, di tengah panasnya isu perang dagang Tiongkok dengan Amerika Serikat pada tahun 2018-2019, negara tersebut justru meningkatkan pembelanjaan militernya. Bahkan, secara aktualnya, anggaran tersebut meningkat sebesar 1,5 kali dari anggaran militer resmi yang dikeluarkan pada tahun 2018 dan 2019 . Kondisi tersebut sejalan terhadap tujuan Tiongkok yang memang mendorong peningkatan belanja militer dengan misi untuk memajukan semua aspek pelatihan militer, persiapan perang, serta dengan

\footnotetext{
31 "China Now World's Second-Biggest Weapons Producer, Report Says," The Japan Times, accessed October 27, 2020, https://www.japantimes.co.jp/news/2020/01/27/asia-pacific/china-worlds-second-biggest-weapons-producer/.

${ }^{32} \mathrm{Ibid}$

${ }^{33}$ Erin Duffin, "Largest armies in the world by active military personnel 2020," Statista, February 25, 2020, https://www.statista.com/statistics/264443/the-worlds-largest-armies-based-on-active-forcelevel/\#: :text=In\%202020\%2C\%20China $\% 20$ had $\% 20$ the,one $\% 20$ million $\% 20$ active $\% 20$ military $\% 20$ personnel.

${ }^{34}$ China Government White Paper, National Defense Construction, http://www.china.org.cn/e-white/5/5.3.htm.
} 
tegas dipergunakan untuk menjaga kedaulatan nasional, kepentingan keamanan dan pembangunan. ${ }^{35}$ Selain itu, peningkatan belanja anggaran militer Tiongkok juga dapat diasumsikan sebagai bentuk respon negara terhadap peningkatan anggaran militer negara rivalnya, Amerika Serikat yang turut menunjukkan peningkatan pada tahun 2018 dan 2019. ${ }^{36}$ Dengan kata lain, dapat dikatakan bahwa dalam kemajuan militernya, alokasi anggaran militer Tiongkok turut dilakukan dalam merespon perkembangan isu maupun anggaran negara lainnya.

Kondisi militer Tiongkok menjadi berbahaya akibat dari perspektif Tiongkok yang menyadari bahwa negara tersebut sulit menyaingi kekuatan militer Amerika Serikat sebagai kekuatan militer utama dunia. Amerika Serikat saat ini memiliki anggaran militer terbesar dengan perolehan sekitar 732 miliar USD atau sekitar 4 kali lipat dari anggaran militer yang secara resmi dikeluarkan oleh Tiongkok. ${ }^{37}$ Kondisi ini juga diimbangi dengan kekuatan militer Amerika Serikat yang tidak lagi diragukan dalam sistem internasional. Dengan terus merespon kekuatan militer rivalnya, Tiongkok mengalami perkembangan signifikan pada instrumen militernya hingga meranah pada pengembangan senjata luar angkasa dan pasukan prajurit dunia maya. ${ }^{38}$ Bersamaan dengan hal tersebut, bila kekuatannya terus menunjukkan penguatan, kekuatan militer yang cenderung ditujukan sebagai upaya defensif dapat beralih menjadi kekuatan ofensif dan melahirkan eskalasi konflik internasional. Terlebih, hal ini mendorong kekuatan negara yang dapat berimplikasi pada bahaya jangka panjang keamanan kawasan dan stabilitas dunia.

\section{Bargaining Power: Langkah Menghindari Ancaman melalui Kekuatan Negara dalam Interdependensi}

Ambisi Tiongkok sebagai negara berpengaruh terbesar di dunia dan Amerika Serikat sebagai kekuatan lama berimplikasi pada pola hubungan kedua negara. Dalam pembahasan sebelumnya, ditunjukkan bahwa kekuatan ekonomi dan finansial Tiongkok berhasil memberikan pengaruh bagi dunia, khususnya bagi Amerika Serikat sebagai negara rivalnya. Kekuatan Tiongkok yang menuai ancaman bagi Amerika Serikat memerlukan tindakan lebih lanjut bagi Amerika Serikat dengan sebuah pendekatan tersendiri. Pendekatan tersebut tentunya ditujukan untuk mengatasi konflik yang terjadi di masa yang akan datang.

Pembahasan dalam artikel ini secara jelas telah menguraikan bagaimana Amerika Serikat memiliki ketergantungan tersendiri pada aspek finansial dan ekonomi Tiongkok. Hal ini menggambarkan kekuatan Tiongkok mampu memengaruhi tindakan negara superpower saat ini. Dalam tinjauan tersebut, kekuatan ekonomi Tiongkok bukanlah kekuatan yang dapat diabaikan begitu saja. Kemampuan Tiongkok dalam menerjemahkan kekuatan ekonominya menjadi kekuatan militer begitu berdampak pada situasi keamanan kedepannya. Namun, melihat kembali hubungan kedua negara, terdapat potensi pendekatan yang dapat dilakukan dalam menghindari ancaman yang dapat membawa kerugian bagi kedua negara tersebut.

\footnotetext{
35 “China boosts defense spending for 2018," Deutsche Welle, accessed October 28, 2020, https://www.dw.com/en/chinaboosts-defense-spending-for-2018/a-42826549.

${ }^{36}$ Berdasarkan data World Bank, tercatat besarnya pengeluaran anggaran militer Amerika Serikat pada tahun 2018 ialah sebesar 682,491 miliar USD dan mengalami peningkatan hingga pada tahun 2019 menembus 731,741 miliar USD. The World Bank, Military Expenditure (Current USD) - United States, accessed October 28, 2020. https://data.worldbank.org/indicator/MS.MIL.XPND.CD?end=2019\&locations=US\&start=2018.

${ }^{37}$ Ibid.

38 Ian Easton, "China's Deceptively Weak (and Dangerous) Military” The Diplomat, accessed October, 29, 2020, https://thediplomat.com/2014/01/chinas-deceptively-weak-and-dangerous-military/.
} 
Pendekatan strategis yang dapat menghindari ancaman bagi kedua negara dapat ditinjau melalui hubungan interdependensi dan bargaining power kedua negara. Relasi interdependensi Amerika Serikat dengan Tiongkok dapat dilihat dari dimensi interdependensi sensitivitas dan kerentanan. Dalam dimensi sensitivitas, kedua negara memiliki saling ketergantungan, baik dalam bidang finansial dan ekonomi. Melalui uraian sebelumnya telah dijelaskan bagaimana Tiongkok memiliki kuasa atas utang Amerika Serikat serta kaitannya dengan mata uang dan perdagangan kedua negara. Akan tetapi, kuasa tersebut tidaklah sepenuhnya hanya dimiliki Tiongkok, melainkan Amerika Serikat turut memiliki otoritas untuk memberikan sanksi dan hukuman pada Tiongkok yang dapat berimplikasi kembali pada perekonomian Tiongkok.

Selanjutnya, dalam dimensi kerentanan, kedua negara memiliki saling ketergantungan yang bergantung pada biaya kerentanan relatif. Berkaitan dengan hal tersebut, untuk menghindari benturan satu sama lain, kedua negara memiliki ketergantungan satu sama lain untuk menopang kekuatan kedua negara dan menghindari benturan konflik yang dapat memperbesar biaya kerentanan negara. Selain itu, bentuk interdependensi kerentanan juga ditinjau melalui kemampuan kedua negara menghindari ketergantungan sepihak dengan melibatkan kekuatan lainnya seperti kebangkitan Tiongkok yang begitu menyadari Amerika Serikat sebagai kekuatan utama sebelumnya.

Dalam gambaran berikutnya, interdependensi Amerika Serikat dan Tiongkok digambarkan dalam fenomena interdependensi asimetris. Hal ini dikarenakan pilihan kedua negara untuk saling bergantung disebabkan oleh respon Tiongkok dalam melihat kekuatan Amerika Serikat yang sulit ditandingi. Berkaitan dengan hal tersebut, Sebagai negara dengan kekuatan terbesar di dunia, Amerika Serikat memiliki efek gentar bagi Tiongkok, serta turut berimplikasi sebaliknya hingga menghasilkan perlombaan kekuatan kedua negara.

Untuk menjaga kestabilan dan menghindari ancaman atas perlombaan kekuatan tersebut, Amerika Serikat dan Tiongkok menyadari bahwa relasi ekonomi mereka dapat membungkam eskalasi konflik yang membuat hubungan menjadi lebih baik, terlebih hal ini dapat ditinjau melalui proses tawar-menawar dalam pendistribusian keuntungan serta posibilitas kerja sama bagi kedua negara. Argumentasi tersebut didukung melalui pendapat Keohane dan Nye (1987) yang menguraikan bahwa interdependensi asimetris dapat menyebabkan munculnya proses bargaining bagi kedua negara. Konsep ini tidak hanya dapat berimplikasi pada perekonomian kedua negara, melainkan juga dapat dikorelasikan dalam efektivitas tindakan rasional negara dalam bentuk kekuatan lainnya.

\section{Kesimpulan}

Realitas kebangkitan Tiongkok menuai dilema bagi Amerika Serikat sebagai negara dengan berkekuatan besar. Dilema tersebut lahir dari kenyataan yang menunjukkan terdapat ketergantungannya dengan Tiongkok terutama dalam aspek finansial dan ekonomi. Terlebih, pertumbuhan kekuatan Tiongkok telah sejalan terhadap kekuatan militer dan pengaruhnya di sistem internasional. Kondisi ini menunjukkan kecenderungan Tiongkok untuk melakukan tindakan ofensif yang merugikan Amerika Serikat. Namun, apabila melihat tinjauan kembali hubungan kedua negara, relasi keduanya menunjukkan peluang yang dapat dimanfaatkan melalui pendekatan strategis negara. Pendekatan tersebut didasari atas kesadaran dan kebutuhan kedua negara dalam perhitungan untungrugi yang kemudian melahirkan interdependensi di tengah kompleksnya hubungan rivalitas yang terjadi. 


\section{Referensi}

Amadeo, K. (2020, October 14). Who Owns the US National Debt? Retrieved from https://www.thebalance.com/who-owns-the-u-s-national-debt-3306124.

Bakry, U. S. (2017). Metode Penelitian Hubungan Internasional. Yogyakarta: Pustaka Pelajar.

China boosts defense spending for 2018. Retrieved October 28, 2020, from https://www.dw.com/en/china-boosts-defense-spending-for-2018/a-42826549.

China now world's second-biggest weapons producer, report says. Retrieved October 27, 2020, from https://www.japantimes.co.jp/news/2020/01/27/asia-pacific/china-worlds-second-biggestweapons-producer/.

China to be the only economy with positive growth in 2020, says IMF report. Retrieved October 19, 2020, from https://news.cgtn.com/news/2020-10-13/World-GDP-to-drop-4-4-in-2020-IMF-UyNuoUIFlC/index.html.

China Government White Paper. National Defense Construction. Retrieved October 30, 2020, from http://www.china.org.cn/e-white/5/5.3.htm.

Debt to the Penny: Fiscal Data: U.S. Treasury. Retrieved October 30, 2020, from https://fiscaldata.treasury.gov/datasets/debt-to-the-penny/debt-to-the-penny.

Easton, I. China's Deceptively Weak (and Dangerous) Military. Retrieved October 29, 2020, from https://thediplomat.com/2014/01/chinas-deceptively-weak-and-dangerous-military/.

Elliott, D. J. (2017, September 22). Living in Two Worlds: Chinese and U.S. Financial Regulation. Retrieved from https://www.csis.org/living-two-worlds-chinese-and-us-financial-regulation.

Erin, D., \& D. (2020, February 25). Largest armies in the world by personnel 2020. Retrieved from https://www.statista.com/statistics/264443/the-worlds-largest-armies-based-on-active-forcelevel/\#: :text=In\%202020\%2C\%20China\%20had\%20the,one\%20million\%20active\%20militar $\mathrm{y} \% 20$ personnel.

Friedman, E. (2013). Building New Vital Mutual Interests for a Better future: A Commentary on Wang Jisi and Kenneth Lieberthal's Addressing US-China Strategic Distrust. Journal of Contemporary China, 22(81), 367-378. https://doi.org/10.1080/10670564.2012.748957.

International Monetary Fund (IMF). (October 2020). World Economic Outlook.

Intragovernmental Holdings and Debt Held by the Public. (2020, October 5). Retrieved from https://www.treasurydirect.gov/govt/charts/principal/principal_govpub.htm.

Is it a Risk for America that China Holds over \$1 Trillion in U.S. Debt? Retrieved October 27, 2020, from https://chinapower.csis.org/us-debt/.

Jisi, W., \& Ran, H. (2019). From Cooperative Partnership to Strategic Competition: A Review of China-U.S. Relations 2009-2019. China International Strategy Review, 1(1), 1-10. https://doi.org/10.1007/s42533-019-00007-w.

Keohane, R. O., \& Nye, J. S. (1973). Power and Interdependence. Survival: Global Politics and Strategy, 15(4), 164-171. https://doi.org/http://dx.doi.org/10.1080/00396337308441409.

Keohane, R. O., \& Nye, J. S. (1987). Power and Interdependence Revisited. International Organization, 41(4).

L., E., \& Lai, C. (2015, June). Renminbi Internationalization: The Prospects of China's Yuan as the Next Global Currency. Retrieved from https://iems.ust.hk/publications/thought-leadershipbriefs/renminbi-internationalization-the-prospects-of-chinas-yuan-as-the-next-global- 
currency\#: :text=Internationalization $\% 20$ of $\% 20$ the $\% 20$ renminbi $\% 20(\mathrm{RMB}, \% 2 \mathrm{C} \% 20$ borrowin g\%2C\%20and\%20investing\%20internationally.

Largest armies in the world by personnel 2020. (2020, February 25). Retrieved from

https://www.statista.com/statistics/264443/the-worlds-largest-armies-based-on-active-forcelevel/\#: :text=In\%202020\%2C\%20China\%20had\%20the,one\%20million\%20active\%20militar $\mathrm{y} \% 20$ personnel.

Lieberthal, K., \& Jisi, W. (2012). Addresing U.S.- China Strategic Distrust. John L. Thornton China Center Monograph Series, 4, 22-23.

National Debt. (2020, September 23). Retrieved from https://www.investopedia.com/updates/usanational-debt/.

President Donald J. Trump is Confronting China's Unfair Trade Policies. (2018, May 29). Retrieved from https://www.whitehouse.gov/briefings-statements/president-donald-j-trump-confrontingchinas-unfair-trade-policies/.

Saunders, P. C., \& Bowie, J. G. (2016). US-China Military Relations: Competition and Cooperation. The Journal of Strategic Studies, 39(5-6), 662-684. https://doi.org/10.1080/01402390.2016.1221818.

The World Bank. China Overview. Retrieved October 27, 2020, from https://www.worldbank.org/en/country/china/overview\#1.

The World Bank. Military Expenditure (Current USD) - United States. Retrieved October 28, 2020, from https://data.worldbank.org/indicator/MS.MIL.XPND.CD?end=2019\&locations=US\&start=2018

Thi Thuy Hang, N. (2016). The United States and China: Can They Cooperate? Asian Affairs(UK), 43(3), 67-77. https://doi.org/10.1080/00927678.2016.1200332.

U.S. Department of Commerce. "National Income and Product Accounts." Bureau of Economic Analysis. $\quad$ Retrieved $\quad$ October 25, 2020, from, https://apps.bea.gov/iTable/iTable.cfm?reqid=19\&step=3\&isuri=1\&nipa_table_list=5\&categori es=survey.

U.S. Department of the Treasury. Major Foreign Holders of Treasury Securities. Retrieved October 27, 2020, from https://ticdata.treasury.gov/Publish/mfh.txt.

United Nations Conference on Trade and Development (UNCTAD). (March 2020). Global Trade Impact of The Coronavirus (COVID-19) Epidemic.

United States Census Bureau. "Trade in Goods with China." Foreign Trade. Retrieved October 26, 2020, from https://www.census.gov/foreign-trade/balance/c5700.html.

United States Government. (2017). National Security Strategy of the United States of America.

What Does China Really Spend on its Military? Retrieved October 27, 2020, from https://chinapower.csis.org/military-spending/\#easy-footnote-bottom-4-142.

Yin, Robert K. (2014). Case Study Research: Design and Methods. Thousand Oaks: Sage Publications. 